\title{
LIFELONG LEARNING AND ACTIVE CITIZENSHIP: THE CASE OF DIRECTING LIFE CHANGE PROJECT
}

\author{
Keith Chandler \\ University of Chester \\ Luis Ochoa Siguencia \\ Akademia Wychowania Fizycznego im. Jerzego Kukuczki w Katowicach \\ Renata Ochoa-Daderska \\ Jan Dlugosz University
}

\begin{abstract}
Learning is our vehicle for change. As a learning community project, we can engage mature people to learn, initially through reflection, that they are empowered to, and can still influence, the direction of their life path. Choices including creative entrepreneurship, active citizenship through volunteering and mentoring, taking up further learning and address the emerging key societal challenge of the need for citizens to be and remain proactive. The aim of this paper is to emphasis in this process and to show how, 'Directing Life Change" ${ }^{, 1}$ project empowers through direct participation, not only of other Learners, with whom relationships are fostered, but also with active participation of potential Life Change actors, locally and internationally. It also seeks to share innovation and experiences with a range of different audiences.
\end{abstract}

List of keyword - Citizenship, Grundtvig, Learning, Life Change, Project management.

\section{Introduction}

It is clear from EU Commission and labour market forecasts that citizens can expect to change career direction 3 to 4 times during life. Despite being an opportunity at the macro-economic level, most individuals will view this as a threat. Therefore we need to empower individuals with life and career change competences, enabling transformation from threat to open opportunity. This project, with 2012 the EU Year of Active Ageing, will investigate and propose an optimum way to face the challenges presented by an ageing population within the new globalised economy, addressing two main priorities: Employment and Engagement in volunteering and membership.

As adult education professionals, we believe Lifelong Learning can and should be an enabler for employability, knowledge transfer, personal autonomy and active citizenship (Aldenmyr, Jepson Wigg, Olson, 2012). The choice of learning for adults must be fit for purpose; attractive for and accessible to adult learners (Brookfield, Holst, 2011); motivated by personal interest, work or enjoyment; encourage exploration and reflection. This will mean they can best contribute 'social capital' as well as 'human capital' through enhanced independence and well-being.

11 Directing Life Change: 527315-LLP-1-2012-1-UK-GRUNDTVIG-GMP. This project is funded with support of the Lifelong Learning Programme of the European Union. http://eacea.ec.europa.eu/llp/funding/2012/selection/documents/sub_progr/grundtviglist_of_successful_projects.pdf 
This project targets men and women aged over 40 with broken career paths, a cohort projected to make up a third of the population in developed countries as the 60 plus age group by 2025 (OECD, 2010). This group has the potential to contribute to their respective economies, be significant consumers, service users and potential actors for change, participating in learning, for up to three further decades. Therefore, the support provided through this project will have an increasing resonance.

Life Change for the better must mean encouraging innovation, imagination and creativity, taking into account contemporary thinking on sustainable well-being, health and quality of life. With a shared need to address these challenges, we will collectively design, develop and disseminate a relevant and transferable andragogy for Life Change which integrates entrepreneurial spirit with learning and citizenship in later life.

We assume key priorities for our target groups to be:

$>$ maintaining employability;

$>$ learning which recognises and values 'real skills', prior experience and knowledge;

$>$ finding meaning and purpose for Life Change;

$>$ enriching social and intellectual lives

Informed choices about Life Change options might be:

i) Non-formal and formal learning: realising potential and broadening the mind. To adapt to change, we should be empowered to learn at all stages in our lives. For some, second chance learning may lead to validation through access to formal opportunities, using flexible methods of recognising prior experience and learning.

ii) Entrepreneurial / labour market activity: for which age should not be a barrier to making a positive contribution. We will work for a reflective dialogue about moving towards portfolio working, developing new forms of enterprise, renewing self-esteem and recognising experience as an achievement, with a transition made as easy as possible.

iii) Mentoring and coaching: encouraging adults to help others, passing on practical experiences as an asset to those, perhaps younger. We will ensure insights into supporting others are explored.

iv) Civic volunteering: a key component of active citizenship. 'Experienced' people can make a significant contribution to others in this way, as well as gaining self-esteem from fulfilling such a role (Zepke, N., 2013).

Underpinning all this is our modus operandi, drawing on five stages of reflection and development with the essential andragogical premise that learning must:

- be a process of active engagement with experience;

- be what people do when they want to make sense of the world;

- encompass skills, knowledge, understanding, values, ideas and feelings 


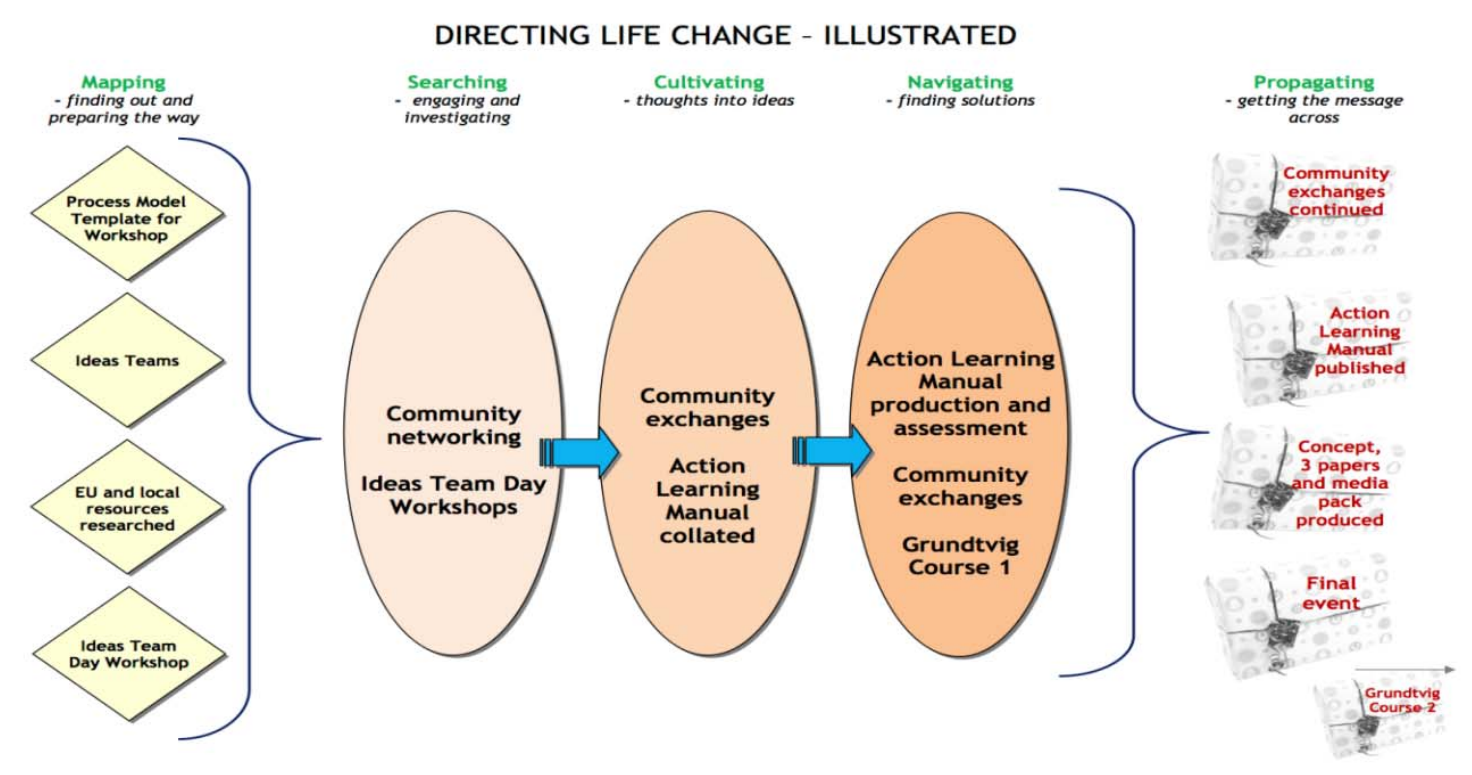

Figure 1 Project implementation

Regardless of national priorities, we share a common recognition of the diversity of approaches to Adult Learning and Education that promote social inclusion and cohesion (Forgeard, Jayawickreme, Kern, Seligman, 2011). Recent research suggests an opportunity for developing shared initiatives:

"In many countries, policy statements adopt a holistic approach to ALE, stressing both economic and non-economic outcomes. However, when it comes to implementation, there is evidence of tension between an emphasis on productivity and competitiveness through human resource development, and an emphasis on human potential development for social inclusion for individuals and social cohesion for societies."

Keogh, H (2009) The State and Development of Adult Learning and Education in Europe, North America and Israel, UNESCO p.11

The Project Implementation seeks to capitalise upon the experience by developing a transnational methodology following research of EU and other agency provenance. By treating Partner institutions as co-learners with target adults, we are addressing a context, encapsulated by the following:

"There is a spectrum of government attitudes to non-formal ALE At one end of the spectrum, the intrinsic value of non-formal ALE is explicitly recognised by the state as a 'public good' as well as a 'private good,' with collective as well as individual benefits contributing to consensus-building and social cohesion. It plays a major role in the promotion of active citizenship and the maintenance of democratic institutions; and a strong role, reaching the individuals least likely to enrol in ALE."

Keogh, H (2009) The State and Development of Adult Learning and Education in Europe, North America and Israel, UNESCO p.18 
Our Consortium shares the common challenge of a greater proportion of older adults and restrictions brought about by economic downturn, especially the effect on working life. Adult's life choice is affected by this, and many are needing to create mid-life choices in addition to the traditional post-compulsory education ones made earlier in their lives:

"Many will also need good guidance later in working life, especially if the incidence of premature withdrawal from the workforce is to fall, reversing the recent trend of earlier retirement despite greater life expectancy."

Hirsch, D (2005) Paying for ourselves as we get older: rethinking resource allocation Institute of Actuaries/Oxford Institute of Ageing Conference "Ageing Population", 8 September 2005

\section{The innovative character od DLC}

We will seek to offer our target group of adults' solutions and approaches which focus on:

- the individual and personalised rather than a set solution;

- what they want and need not what others think is important;

- bringing support to a community location rather than it being disparate and detached;

- being the subject for rather than an object of change;

- Life Change and choice rather than only labour market routes;

- creating their own direction, rather than merely 'using' services;

- being part of an open community rather than a formal process;

- finding 'emancipation'; rather than being offered a limited choice

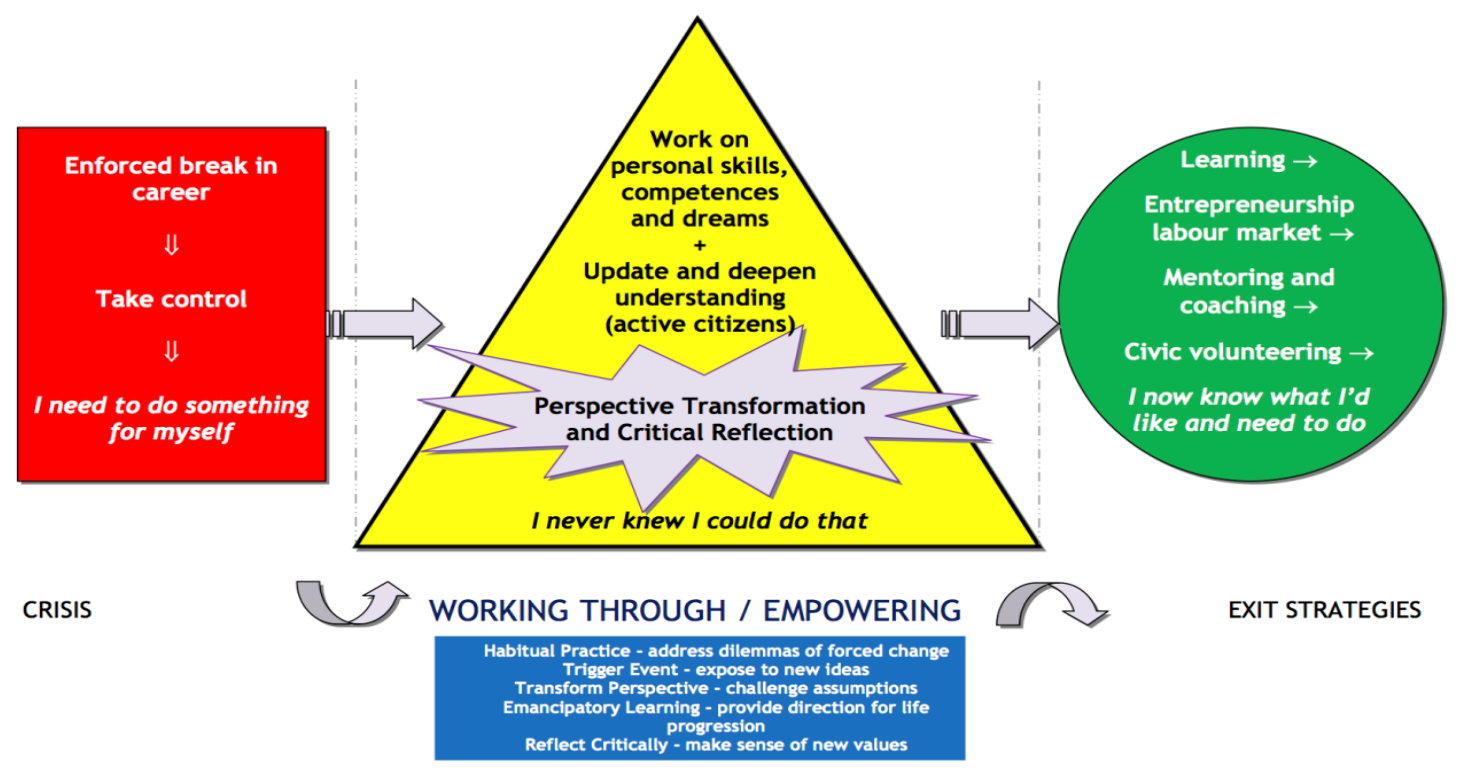

Figure 2 DLC process 


\section{Aims, objectives and aspirations}

- To offer alternative learning approaches for adults post 40 so they are enabled to:

- 'take control' after an enforced break in their career through being directed towards pathways that draw upon their experience, enhance and improve their existing situation: "I need to do something for myself."

- update and deepen their understanding to better enable them to reintegrate into society and enhance their status as active citizens: "I might be able to give something back."

- bring out their personal skills and competencies, dormant and perhaps unimagined until this point: "I never knew I could do that."

- engage and/or re-engage in personal development of their choice which might for example include:

- non-formal and formal learning

- entrepreneurial / labour market activity

- mentoring and coaching

- civic volunteering "I now know what I'd like and need to do."

B) Develop an internationally relevant methodology by:

3) drawing upon the experience and expertise of a specially established Ideas Team, ensuring relevance and transferability

4) enable life-change to be directed appropriately to meet a range of contexts

5) encourage cooperation and knowledge-exchange between adult learning practitioners (Sandlin,J., Wright. R. and Clark, C., 2011).

provide a personal and professional learning manual for institutions across Europe to develop Pointing in Your Direction initiatives of their own

\section{Our aspirations are to:}

- shift the paradigm from negativity about the future towards finding emancipation by fresh thinking through reflection;

- create new practice by bespoke life-change opportunities for adults $40+$;

- bring support to accessible, relevant community locations;

- emphasise individual, personalised solutions as the subject for, not the object of, change;

- provide both formal and informal learning;

- empower to create direction not just to use services

\section{Project progression logic}

To succeed, we need to engage with and learn directly from adults 40+, from existing actors and actions locally. Through reflective co-learning (McMillan, J., 2011), we will deliver a template with 'real' solutions, before sharing these, practically and flexibly, with those who can effect life change.

To achieve this, five development Phases drive our Methodology:

Milestones (by month) apply to all Partners unless stated. 
DIRECTING LIFE CHANGE - PROGRESSION

\begin{tabular}{|c|c|c|c|c|}
\hline $\begin{array}{l}\text { Mapping } \\
\text { - finding out and } \\
\text { preparing the way }\end{array}$ & $\begin{array}{l}\text { Searching } \\
\text { - engaging and } \\
\text { investigating }\end{array}$ & $\begin{array}{l}\text { Cultivating } \\
\text { - thoughts into ideas }\end{array}$ & $\begin{array}{l}\text { Navigating } \\
\text { - finding solutions }\end{array}$ & $\begin{array}{l}\text { Propagating } \\
\text { - getting the message } \\
\text { across }\end{array}$ \\
\hline $\begin{array}{c}\text { OCT } 12 \text { - JAN } 13 \\
\text { (4 months) }\end{array}$ & $\begin{array}{l}\text { FEB } 13 \text { - MAY } 13 \\
\text { (4 months) }\end{array}$ & $\begin{array}{c}\text { JUN } 13-\text { OCT } 13 \\
\text { (5 months) }\end{array}$ & $\begin{array}{c}\text { NOV } 13 \text { - MAY } 14 \\
\text { (7 months) }\end{array}$ & $\begin{array}{c}\text { JUN } 14 \text { - SEP } 14 \\
\text { (4 months) }\end{array}$ \\
\hline $\begin{array}{l}\text { Meeting 1: Kick-off UK } \\
\text { Process Model } \\
\text { Template for } \\
\text { Workshop designed } \\
\text {-process of 'Perspective } \\
\text { Transformation and } \\
\text { Critical Reflection': } \\
\text { - Habitual Practice. } \\
\text { address dilemmas of } \\
\text { forced change } \\
\text { - Trigger Event - expose to } \\
\text { new ideas } \\
\text { - Transform Perspective - } \\
\text { challenge assumptions } \\
\text { - Emancipatory Learning - } \\
\text { provide direction for life } \\
\text { progression } \\
\text {-Reflect Critically - make } \\
\text { sense of new values } \\
\text { 'Ideas Teams' set up } \\
\text { by engaging local } \\
\text { networks and agencies } \\
\text { EU provenance and } \\
\text { local resources } \\
\text { researched and } \\
\text { collated } \\
\text { data search, collection } \\
\text { and dialogue via networks } \\
\text { Local Ideas Team Day } \\
\text { Workshop } 1 \text { held } \\
\text { to understand process, } \\
\text { explore co-learning, } \\
\text { determine support }\end{array}$ & $\begin{array}{l}\text { Community Networking } \\
\text { enacted } \\
\text { dialogue with those to } \\
\text { whom eventual signposting } \\
\text { is to be made } \\
\text { Meeting 2: } \\
\text { Development held in } \\
\text { Austria } \\
\text { feedback to Partners } \\
\text { Local Ideas Team Day } \\
\text { Workshop } 2 \text { held } \\
\text { co-learning action sets, } \\
\text { collect ideas, } \\
\text { individualised learning } \\
\text { Local Ideas Team Day } \\
\text { Workshop } 3 \text { held } \\
\text { action sets, experiential } \\
\text { learning, prepare for share } \\
\text { Meeting } 3\end{array}$ & $\begin{array}{l}\text { Meeting 3: Ideas Team 1st } \\
\text { share held in Spain } \\
\text { Ideas Team reps share ideas, pass } \\
\text { on material and Project dialogue } \\
\text { Community exchanges } \\
\text { established } \\
\text { open out to make wider } \\
\text { engagement } \\
\text { In-service Courses planned } \\
\text { capturing 'live' activities for CPD } \\
\text { funding application } \\
\text { Action Learning Manual } \\
\text { collated } \\
\text { choice of best ideas for relevance } \\
\text { and transferability } \\
\text { Final Dissemination Event } \\
\text { prepared } \\
\text { anticipate, engage interest in on- } \\
\text { going process across networks } \\
\text { QA model implemented } \\
\text { feedback on-going activities, set } \\
\text { improvement parameters }\end{array}$ & $\begin{array}{l}\text { Action Learning Manual: content assessed, } 1^{\text {st }} \text { draft } \\
\text { compiled, } 2^{\text {cd }} \text { draft modified, final draft completed } \\
\text { staged process using learning material from 'real-life' Ideas } \\
\text { Teams } \\
\text { QA model evaluated } \\
\text { reflect on implementation, instigate changes } \\
\text { Meeting } 4 \text { : Ideas Team } 2 n d \text { share held in Hungary } \\
\text { share ALM draft and plan testing of exchanges } \\
\text { Community exchanges in place and tested } \\
\text { open collaborative environments, small group contextualisation } \\
\text { of Life Change } \\
\text { In-service Course held in Poland } \\
\text { will showcase ALM principles to Life Change professionals } \\
\text { European Report produced } \\
\text { reflection on national challenges and possible solutions }\end{array}$ & $\begin{array}{l}\text { Community exchanges } \\
\text { continuing } \\
\text { on-going cooperation and } \\
\text { knowledge-exchange } \\
\text { Action Learning } \\
\text { Manual Published } \\
\text { available throughout } \\
\text { networks } \\
\text { Concept and } 3 \text { PDF } \\
\text { Papers, Media Pack } \\
\text { produced } \\
\text { our transformative process } \\
\text { exposed to different } \\
\text { audiences } \\
\text { Meeting: Final held in } \\
\text { Italy } \\
\text { wrap up all Project issues } \\
\text { and requirements } \\
\text { Final Event held in } \\
\text { Italy } \\
\text { Dissemination Report } \\
\text { finalised ( } \rightarrow \text { ) } \\
\text { Final Report to EACEA } \\
\text { submitted ( } \rightarrow \text { ) } \\
\text { In-service Course held } \\
\text { in Finland ( } \rightarrow \text { ) }\end{array}$ \\
\hline
\end{tabular}

Figure 3 Project Milestones

\section{1) Mapping}

Months 1-4 - finding out and preparing the way

Guides produced (1) By Co-ordinator.

Meeting 1: Kick-off held in UK (1). To outline working practices.

QA model designed (2) By Co-ordinator with QA expert, then shared.

Process Model Template for Workshop designed (3) Process of 'Perspective Transformation and Critical Reflection':

- Habitual Practice: address dilemmas of forced change

- Trigger Event: expose to new ideas

- Transform Perspective: challenge assumptions

- Emancipatory Learning: provide direction for life progression.

- Reflect Critically: make sense of new values.

'Ideas Teams' set up (3) By engaging local networks and agencies.

EU provenance (3) and local resources (4) researched and collated. Data search, collection and dialogue via networks.

Local Ideas Team Day Workshop 1 held (4) To understand process, explore colearning, determine support . 


\section{2) Searching}

Months 5-8 - engaging and investigating.

Community networking enacted (5). Dialogue with those to whom eventual signposting is to be made.

Meeting 2: Development held in Austria (5). Feedback to Partners.

Local Ideas Team Day Workshop 2 held (6). Co-learning action sets, collect ideas, individualised learning.

Local Ideas Team Day Workshop 3 held (8). Action sets, experiential learning, prepare for share Meeting 3.

\section{3) Cultivating}

Months 9-13 - thoughts into ideas.

Meeting 3: Ideas Team 1st share held in Spain (9). Ideas Team reps share ideas, pass on material and Project dialogue.

Community exchanges established (10). Open out to make wider engagement

In-service Courses planned (10). Capturing 'live' activities for CPD funding application.

Action Learning Manual (ALM) collated (12). Choice of best ideas for relevance and transferability.

Final Dissemination Event prepared (12). Anticipate, engage interest in ongoing process across networks

QA model implemented (12). Feedback on-going activities, set improvement parameters.

\section{4) Navigating}

Months 14-20 - finding solutions.

ALM: content assessed (14), $1^{\text {st }}$ draft compiled (16), $2^{\text {nd }}$ draft modified (17), final draft completed (19). Staged process using learning material from 'reallife' Ideas Teams.

QA model evaluated (15). Reflect on implementation, instigate changes.

Meeting 4: Ideas Team 2nd share held in Hungary (16). Share ALM draft and plan testing of exchanges.

Community exchanges in place (15) and tested (17). Open collaborative environments, small group contextualisation of Life Change.

In-service Course held in Poland (17). Will showcase ALM principles to Life Change professionals.

European Report produced (19). Reflection on national challenges and possible solutions.

\section{5) Propagating}

Months 21-24 - getting the message across.

Community exchanges continuing (20). On-going cooperation and knowledgeexchange.

ALM Published (23). Available throughout networks.

Concept and 3 PDF Papers, Media Pack produced (22). Our transformative process exposed to different audiences. 
Meeting: Final held in Italy (22). Wrap up all Project issues and requirements Final Event held in Italy (22).

Dissemination Report finalised (25).

Final Report to EACEA submitted (25).

In-service Course held in Finland (28).

\section{Target groups}

The target group will be involved in all 5 phases, their engagement taking the following forms:

Months 1 to 4 Mapping: Towards phase end, Ideas Teams will help to identify and appraise existing processes and structures.

A first local workshop will enable team members as co-learners to gain an understanding of the project's 'modus operandi' i.e. Perspective Transformation \& Critical Reflection.

Months 5 to 8 Searching: Three local workshops in each partner locality will generate ideas and promote reflection on life paths, collated and fed back to Partners and peers through the communication platform. This determines required future support and ensures an individualised focus.

Months 9 to 13 Cultivating: Two members of each Ideas Team will participate in a Transnational Meeting in Spain (1st share), assisted in communication and language skills to optimise contribution.

Community exchanges open to each locale will be set up to enable further involvement of peers, facilitated by Ideas Team members for continual ideas generation and data capture. These will facilitate skills, mentoring and volunteering to be practiced and honed in real life situations.

Ideas from activities will be encapsulated in the first stage (collation) of the ALM.

Months 14 to 20 Navigating: Each Ideas Team will be expanded to include more peers. Testing of the Draft ALM will take place through trialling and feedback from this new cohort. Here, actively experiencing the self-assessment element will best test its application.

Two members of each team will participate in a Transnational Meeting in Hungary (2nd share) to best contrast and compare shared ideas.

At this stage, experiences and ideas of participants will contribute to the preparation of the Final Dissemination Event (FDE).

Months 21 to 24 Propagating: Alongside roles as mentors and volunteers within Community exchanges, participants will contribute advice and guidance to best define the audience for the final Draft ALM and on the optimum use of multimedia.

They will also contribute to the Transnational Launch and some will be invited to participate in the FDE in Italy.

Having undergone the transformational processes expounded by the project, participants are crucial to effective exploitation and will act as advisors and reference points beyond the life of the project. 
Adults aged 40+ whose career path has been broken will remain the predominant beneficiaries from this project. The Perspective Transformation \& Critical Reflection process is at the core of the ALM. Through this:

- Adult learners will remain economically, educationally and/or voluntarily active;

- One 'Directing Life Change' facility in each locality will have been established;

- Community exchanges will continue to provide focussed and individualised solutions.

The ALM will allow this process to be replicated for potentially significant further benefit beyond the duration of the project. Initially targeted by the inservice Grundtvig-funded courses for adult learning practitioners offered in Months 17 (during) and 28 (post-project). Also, the Final Dissemination Event and other work in both the Dissemination and Exploitation Work Packages aim to imbue and subsume the Methodology as part of good practice. In addition, we will all seek to get endorsement from respective local, regional and national agencies to take the initiative forward.

Target groups, accessed through the 8 Partners' increasingly broadening EU and wider networks are:

- Institutions and organisations wishing to direct professional and voluntary life change;

- Professionals with Life Change management roles;

- Affiliated bodies linked to peer networks

These Partner and additional Institutions will be enabled to:

- use the processes and materials for future initiatives;

- establish their own new international links within mutually supportive networks;

- engage with fresh cohorts of similar target learners across a broader tranche of European and Third Country Partners

After the project, Consortium Partners will be set to cascade information learned through their respective networks. Not only this, but we anticipate that the Project and its products will have served as a catalyst towards further activity in the areas of Active Ageing especially. The dialogue established, which, in our experience carries on long after any project has completed, can only be enhanced by the research element we have added to this proposal. Whilst trying to make practice in the future easier and more relevant for practitioners and facilitators, we also recognise the value of stimulating further questioning, debate and curiosity to drive our future engagement in the field (Jackson, 2012). The value of networks that are, and remain, relevant for both Target Learners and those concerned with their engagement is paramount to the continued efficacy of the reach of the DLC Project. Without a purpose that is meaningful for all concerned, we realise that there is a risk nothing will really happen. 
Therefore, all Partners will be trying to ensure that the aftermath of this Project will contain a lasting legacy through:

- discussion and debate of the Methodology presented (aided by the Papers and other Research);

- adoption of similar andragogical approaches to enabling learners to develop learning for their peers;

- instigating future initiatives and linking them as consequential to the DLC Project

\section{Partners}

$>$ University of Chester, UK

$>$ Università delle LiberEtà del Fvg, Udine, Italy

$>$ Associació Catalana de Formació Polivalent Aplicada, Baobab, Spain

$>$ TREbAG Property and Project Management Ltd, Hungary

$>$ Wyższa Szkoła Lingwistyczna, Poland

$>$ Kärntner Volkshochschulen, Austria

$>$ University of Helsinki Palmenia Centre for Continuing Education, Finland

$>$ Multi-Disciplinary Centre, Modi'in Municipality, Israel

\section{Conclusion}

The main implementation process will be the work of a proactive Ideas Team in each of 8 countries sharing with international counterparts and national communities.

Partners will maximise networks and community links to locate participants to engage in the transformation and reflective process and thereby benefit from signposting and developing their own selves through the logic of the methodology.

Each team will commit to and be ambassadors for the entire project.

Representatives will be in the ratio of: 2 Partners, 3 to 8 Adults and 2 to 3

Communities. Some Adults will need to be able and willing to travel.

Creation of the Action Learning Manual (ALM) will be facilitated through the Ideas Teams. Ideas beyond this will continue as the focus of Community exchanges in each locality, facilitated by partners working with appropriate local expertise, designed to address specific local and actual issues efficiently and effectively.

\section{Acknowledgement}

This research paper has used data recollected by Directing Life Change project: 527315-LLP1-2012-1-UK-GRUNDTVIG-GMP. This project is funded with support of the Lifelong Learning Programme of the European Union. All here provided information and documentation reflects the views only of the authors, and the Commission cannot be held responsible for any use which may be made of the information contained therein. 


\section{References}

1. Aldenmyr, S., Jepson Wigg, U., Olson, M. (2012). Worries and possibilities in active citizenship: Three Swedish educational contexts Education. Citizenship and Social Justice, 7 (3), 255-270

2. Brookfield, S., and Holst, J. (2011). Radicalizing learning: Adult education for a just world. San Francisco, CA: Jossey Bass.

3. Forgeard, M., Jayawickreme, E., Kern, M., and Seligman, M. (2011). Doing the right thing: Measuring wellbeing for public policy. International Journal of Wellbeing, 1(1), 79-106.

4. Jackson. N. (2012). Lifewide Learning, Education \& Personal Development e-book. http://lifewideeducation.co.uk/page/lifewide-learning-education-personal-developmente-book. Lifelong Learning Council Queensland Inc. (2012) What is lifelong learning? Retrieved from http://www.llcq.org/01_cms/details.asp?ID=12.

5. Keogh, H (2009) The State and Development of Adult Learning and Education in Europe, North America and Israel, UNESCO p.11

6. McMillan, J. (2011). What happens when the university meets the community? Service learning, boundary work and boundary workers. Teaching in Higher Education, 16(5), 553-564.

7. Sandlin,J., Wright. R. and Clark, C. (2011). Reexamining theories of adult learning and adult development through the lenses of public pedagogy. Adult Education Quarterly, 63(1), 3-23.

8. Zepke, N. (2013). Lifelong education for subjective well-being: how do engagement and active citizenship contribute?, International Journal of Lifelong Education, DOI:10.1080/02601370.2012.753125

$\begin{array}{ll}\text { Keith Chandler } & \begin{array}{l}\text { University of Chester } \\ \text { e-mail: k.chandler@chester.ac.uk }\end{array} \\ \text { Luis Ochoa Siguencia } & \begin{array}{l}\text { Akademia Wychowania Fizycznego im. Jerzego } \\ \text { Kukuczki w Katowicach } \\ \text { e-mail: 1.ochoa@awf.katowice.pl }\end{array} \\ \text { Renata Ochoa-Daderska } & \begin{array}{l}\text { Jan Dlugosz University } \\ \text { e-mail: r_ochoa@tvksmp.pl }\end{array}\end{array}$

